\section{Trade, openness, and domestic conflict: an empirical investigation for Latin America}

\section{Prasad S. Bhattacharya and Dimitrios D. Thomakos}

$\mathrm{C}$ onflict over resources and output is an important topic of economic and sociopolitical research. In an attempt to devise credible mitigation mechanisms, the World Bank project on the Economics of Civil War, Crime, and Violence is one of many examples of ongoing research that analyze occurrence and duration of conflict. ${ }^{1}$ One of the most important results arising from this research is that increased trade openness may have conflict-mitigating effects. ${ }^{2}$ But over-reliance on primary commodity exports, some studies suggest, can lead to more conflict. ${ }^{3}$ (This so-called "natural resource curse" appears especially pronounced for Africa. ${ }^{4}$ ) It is also established that underlying sociopolitical and institutional structures play significant roles in starting and sustaining conflicts. ${ }^{5}$ The literature on domestic and international conflict focuses on either all countries in the world, or only on the African continent. ${ }^{6}$ Because continents and regions differ in various sociopolitical and economic aspects, as well as with respect to other factors that underlie conflict, it stands to reason to carry out additional region-specific studies. Accordingly, we analyze domestic conflict in Latin America (for the 1973-1995 time period).

Latin America has witnessed a significant drop in domestic conflict since the mid1980s. As this coincided with a general tendency of opening up its domestic markets to world trade, it is plausible that trade and openness may have helped to mitigate conflict. Nevertheless, while for some Latin American countries trade liberalization resulted in reductions in the relative prices of agricultural goods (i.e., below autarky prices), which in turn might be expected to stimulate economic activity and help mitigate conflict, ${ }^{7}$ in other countries agricultural prices rose above international levels, and this might be expected to foster conflict for the opposite reason (as has been observed in Africa, for instance).

Based on this sort of reasoning, on which we elaborate later on, we empirically explore the links among trade, openness, and domestic conflict in Latin America. ${ }^{8}$ By making use of data on conflict deaths that arose in clashes between government and rebel forces, we focus on two important questions. First, how do variations in trade openness affect the likelihood of starting a domestic conflict or elevate a low-intensity conflict to a high-intensity conflict? Second, once initiated, how do variations in openness affect the duration of conflict? Conflict onset and conflict duration are the key variables to be explained. The underlying idea is that, through various channels, trade and trade openness may affect incentives and opportunities to engage in conflict, just as it can affect participants' ability to sustain conflict.

To address these issues, we rely on a theoretical model proposed by Garfinkel,
Skaperdas, and Syropoulos that centers on the role of primary goods in the economy. In brief, the argument is that the primary goods sector, i.e., agriculture in Latin America, (i) is most likely to create conflict due to the high level of resources involved and due to the temptation to exert control over them, and (ii) is likely to exhibit a significant change in relative commodity prices as a result of trade liberalization. The extent of trade liberalization should influence, by moderating incentives and opportunities, whether conflicts are stimulated and sustained, or abetted. After controlling for a variety of confounding sociopolitical and economic factors, our empirical findings suggest that agricultural exports as a percentage of tota exports play an important role for conflict onset (occurrence) and duration (sustenance) in Latin America. As in Africa, over-reliance on commodity exports is a conflict risk factor. This needs to be addressed in devising conflict resolution policies. Further, we find that while overall trade openness reduces the probability of domestic conflict onset, this does not play a role in conflict sustenance.

\section{The economic argument}

The framework of Garfinkel, Skaperdas, and Syropoulos focuses on domestic conflict over a tradable resource. They show that trade may reduce welfare if it leads to the intensification of conflict and loss of resources associated with conflict. In their study, they analyze two questions. First, whether more openness reduces conflict by making participants richer and more open to "deal making" and, second, whether greater openness induces more wasteful competition and conflict by making some resources and commodities more valuable. This can happen when trade openness influences the value of the resource, as openness affects the price of the tradable resource.

By way of illustration, consider the case of agricultural products. If agricultural products are generating more value (return) after being traded in the world market, domestic participants in that trade would like to invest more resources (in terms of inputs) for continuation of that trade. Domestic conflict can then arise if either the ownership of these resource for producing that tradable commodity is not well defined or if these resources are confined to a certain proportion of the population.

Our work adds to that of Garfinkel, Skaperdas, and Syropoulos in that it focuses on the value of a tradable commodity and the value of the (not necessarily tradable) resources to produce that commodity under openness. Overall welfare, in terms of the reduction in the number or intensity of conflict, increases if the return from commodity trade is higher than the "return" from any potential conflict arising from the ownership of resources to produce those commodities. Conversely, if the return from commodity trade is of such a magnitude that it becomes almost impossible to avert conflict over control of the strategic ownership of resources to produce those commodities, then more openness may be a "curse" inasmuch as it enhances the number or intensity of domestic conflict. This reflects the "natural resource curse" idea mentioned earlier. 
These points and our refinement cater to domestic conflict onset, which is the first question we address in this article, i.e., how do variations in trade openness affect the likelihood of starting a domestic conflict or elevate a low-intensity conflict to a highintensity one?

To relate this to Latin America, consider conflict over land. To be specific, parties in conflict want to control land that provides them with opportunities to produce agricultural goods or extract natural resources that they can trade in the world market and generate income. This conflict over a resource has been played out time and again in Latin America, where land distribution is skewed. ${ }^{10}$ When countries open up and start trading agricultural goods that use land as an input, the prices of these goods increase as compared to their autarkic (or no-trade) price. Consequently, stakes from conflict over higher-valued land increase once parties control and use that resource for future production of agricultural goods. Thus, the question that emerges for empirical investigation is whether increased trade openness (measured in terms of exports and imports of goods as a percentage of GDP) leads to an increase or decrease of overall conflict onset and intensity in Latin America.

Garfinkel, et al.'s framework is static; it sheds no light on conflict sustenance. However, looking at the previous example, and specifically for the case of Latin America, one question to follow logically is this: do changes in openness or variation in openness lead to domestic conflict sustenance? For example, if parties engaging in trade are always generating enough gains to outweigh the loss arising from potential conflict, would not they be interested in engaging in more trade and less conflict? Put differently, the probability that domestic conflict is going to be less (or more) than before again depends on the incremental benefits (or costs) being accrued over time. This is the second issue we pointed to before: once initiated, how do variations in openness affect the duration of conflict? Accordingly, we look empirically at the following question: what role does trade openness and other factors and tradable commodities (as a result of trade openness) play in explaining the probability that domestic conflict is going to be continued (or abetted) in the next period?

\section{Data and methodology}

In our study, the variable to be explained is "domestic conflict" for seventeen Latin American countries, collected from the Armed Conflict Dataset. ${ }^{11}$ In this data set domestic conflict is defined as "internal conflict within a country between a government and one or more opposition groups, with no interference from other countries." Within this definition, there are four sub-categories: (1) no internal conflict; (2) internal minor armed conflict: at least 25 battle-related deaths per year and fewer than 1,000 battle-related deaths during the course of the conflict; (3) internal intermediate armed conflict: at least 25 battle-related deaths per year and an accumulated total of at least 1,000 deaths, but fewer than 1,000 per year; and (4) internal war: at least 1,000 battle-related deaths per year. The choice of time period,
1973 to 1995 , is guided by data availability for some of the explanatory variables as well as by virtual nonoccurrence of internal conflicts in most of the sample countries before 1973 (except for Colombia and Guatemala). Some authors have argued that sustenance of civil war can also be attributed to the emergence of a large international arms market in the 1980s, and so our choice of time period addresses this issue as well. ${ }^{12}$ Finally, our focus is on any internal conflict, not on civil war per se.

We use various measures of trade openness and trade variables as covariates or explanatory variables in our analysis. They include: (i) trade openness: the ratio of exports and imports as a percentage of gross domestic product (GDP); (ii) the proportion of agricultural exports in total exports; (iii) food, beverage, and tobacco exports as a percentage of trade; (iv) basic metal exports as a percentage of trade; (v) food and beverage imports as a percentage of trade; and (vi) fuel imports as a percentage of total trade. Data for all of these variables were collected from various issues of the Statistical Abstracts of Latin America.

As control variables, we use the countries' arable land area as a proportion of total land area (taken from World Development Indicators) and "landlock," the percent of land area beyond hundred kilometer of ice-free coast (taken from the web site of the Center for International Development at Harvard University). After controlling for various region-specific factors, the econometric part of our work employs three modeling techniques (ordinal regression, Markov switching, and proportional hazard models) to explain conflict onset/intensity and duration based on the trade and openness variables only. We check the robustness of our results by using additional explanatory and control variables, besides the trade and openness variables. ${ }^{13}$

\section{Findings}

Our overall results show, first, that increased trade openness reduces the chance of domestic conflict onset and that variation in trade openness therefore does affect the likelihood of commencement of domestic conflict and, second, that over-reliance on agricultural exports (a consequence of increased trade openness) plays the main role in conflict sustenance, highlighting that, once initiated, variations in openness affect the duration of conflict. Both findings remain robust in the presence of various sociopolitical, institutional, and economic controls. More specifically, we find:

- Over-reliance on agricultural exports as a proportion of total export generates a moderate to high conflict onset probability as well as a high conflict sustenance probability.

- Taking all the export variables together, and after controlling for region-specific factors, agricultural exports and basic metals exports as a proportion of total exports help to sustain domestic conflict. The use of arable land area, as a proportion of total land area, and the landlocked region as control variables, provides good intuition in explaining these results on domestic conflict. Latin 
America is characterized by a high level of land and asset inequality. Keeping the high level of land inequality constant, possession and return from arable land becomes the point of contention and leads to conflict. This tallies with Garfinkel, et al.'s conjecture. With the domestic market opening up for trade, Latin American countries have a comparative advantage in the export of agricultural goods ${ }^{14}$ and basic metals. As prices of these tradable goods increase, returns from resources used to produce these goods also go up. Consequently, appropriating these resources becomes beneficial for the parties engaged in production of those tradable goods. This process can initiate conflict or can elevate an existing conflict from a low-intensity to a high-intensity one.

- Our results support another of Garfinkel, et al.'s conjectures: if the international price of the contested resource is sufficiently higher than the no-trade, autarkic price, then more gains from trade will outweigh the costs of arming. The empirical results from food, beverage, and tobacco exports as a percentage of total exports show minimal conflict onset probabilities and low conflict sustenance probabilities over the years.

- We also find that in the presence of increased openness, high intensity domestic conflicts reduce to low intensity conflicts. This result is clearly important and remains robust when we control for underlying economic, sociopolitical, and institutional factors. The inter-temporal effects of openness on domestic conflict seem to be weak: we do not find any significant effect of openness toward conflict sustenance overtime.

All of our results provide suggestive evidence that trade openness and its associated measures do have a role to play in explaining variations in domestic conflict in the Latin American region between 1973 and 1995. A favorable policy mechanism for complete conflict mitigation should probably take our findings into account.

\section{Concluding remarks}

To explain domestic conflict in Latin America between 1973 and 1995, we rely on a plausible theory concerning the evolution of prices of trade variables. While the existing literature on domestic and international conflict pays much attention either to all of the world's countries, or only to the African region, we follow the suggestion of Sambanis for additional region-specific work.

Opening their domestic markets to participate more in world trade as from the mid-1980s, the data show that there was a significant drop in domestic conflict in the Latin American region. Therefore, it appears that trade can be beneficial in mitigating conflict. However, over-reliance on primary commodity exports may actually enhance domestic conflicts, as happened in African countries after they started interacting with world markets. Naturally, careful attention is needed to track down the reasons that may initiate, enhance, and prolong domestic conflict even after increased participation in the world market.

In our empirical analysis we use an indirect approach, taking the level of tradable goods' output and relate that with the prices or returns to the resources needed to produce those goods. The idea is that as a country opens up to world trade, the prices of exportables and importables change, depending on whether that country has a comparative advantage in some of the exportables being produced or comparative disadvantages from some of the importables being shipped into that country. There is strong evidence that Latin American countries have comparative advantage in agricultural goods exports. For some of the countries in the region, opening up to trade reduces the relative price of agricultural goods below that of no-trade price levels; this helps to mitigate conflict. Conversely, some of the countries in the sample show that agricultural goods prices go up beyond the international level, leading to an increase in conflict. After controlling for various sociopolitical and economic factors the literature already identified as explaining domestic conflict, we find that agricultural exports as a percentage of total exports play an important role for conflict occurrence in this region. Our results also suggest that overall trade openness reduces Latin American domestic conflict.

In our study, we go beyond Garfinkel, et al.'s static framework and also explore how trade and openness variables play a role in sustaining conflict overtime in the Latin American region within the selected time frame. Our analysis shows that only over-reliance on agricultural exports, and not trade openness per se, explains domestic conflict over time in the Latin American countries. Therefore we argue that even if overall trade openness is beneficial for abetting conflict, its role in conflict mitigation over an extended time period may be small. Instead, more focus needs to be put on the optimal, rather than maximal, reliance on agricultural exports for conflict mitigation.

Notes

Prasad S. Bhattacharya, the corresponding author, is Lecturer in Economics and Finance in the School of Accounting, Economics, and Finance, Deakin University, Australia, and can be reached at prasbhat@deakin.edu.au. His research areas include empirical analysis of conflict, civil war, and terrorism as well as applied growth and development. Dimitrios D. Thomakos is Associate Professor in Applied Econometrics at the Department of Economics, University of Peloponnese, Greece. He can be reached at thomakos@uop.gr. His research interests include applied international trade and economic development. We thank Jurgen Brauer, Costas Syropoulos, Peter Thompson, Cem Karayalcin, Nejat Anbarci, Hristos Doucouliagos, Mehmet Ulubasoglu, and seminar participants at the 24th International Symposium on Forecasting and the 37th Australian Economic Society Meeting in Australia for useful comments and suggestions. All remaining errors are our responsibility. 
1. Sambanis (2004) has a comprehensive discussion regarding case study-based conflict and civil war analysis across the world.

2. See, e.g., Hegre (2002).

3. E.g., Collier and Hoeffler (2004).

4. See, e.g., Ross (2004).

5. See, among others, Collier and Hoeffler (1998); Sambanis (2004).

6. See, inter alia, Hegre (2002); Fearon and Laitin (2003); Collier and Hoeffler (2004).

7. On this point, see Garfinkel, Skaperdas, and Syropoulos (2005).

8. An exact definition of domestic conflict and the relevant data are provided in Gleditsch, Wallensteen, Eriksson, Sollenberg, and Strand (2002). Sample countries are Argentina, Bolivia, Brazil, Chile, Colombia, Costa Rica, Ecuador, El Salvador, Guatemala, Honduras, Mexico, Nicaragua, Panama, Paraguay, Peru, Uruguay, and Venezuela.

9. Garfinkel, Skaperdas, and Syropoulos (2005).

10. See Lipton, Eastwood and Kirsten (2002) who note that the land Gini coefficient in Latin American countries is 0.86 - the highest in the world.

11. Gleditsch, Wallensteen, Eriksson, Sollenberg, and Strand (2002).

12. See Collier, Hoeffler, and Soderbom (2004).

13. Additional controls are (i) land area, million square kilometers (source: Center for International Development, Harvard University); (ii) elevation, measured as mean elevation in hundreds of meters above sea level (same source); (iii) land inequality (Lipton, Eastwood, and Kirsten, 2002); and (iv) ethno-linguistic fractionalization (La Porta, et al., 1998). Additional explanatory variables apart from trade and trade openness variables include GDP growth per capita, rural population as a percentage of total population, rural population annual growth rate, infant mortality rate, and a sociopolitical index with weights on cabinet and constitutional changes, assassinations, guerrilla activities, revolutions, strikes, government crises, coups, party fractionalization, purges, and riots. After incorporating these additional controls, the overall findings remain essentially the same as those reported in the main text. Details are available from the corresponding author or at

http://www.deakin.edu.au/buslaw/aef/publications/workingpapers/2006-02eco.pdf.

14. See Ocampo (2004) for an important discussion articulating this point and the related consequences. Also see Fraga (2004) for an informative perspective on Latin America.

\section{References}

Collier, P. and A. Hoeffler. 1998. "On the Economic Causes of Civil War." Oxford Economic Papers, Vol. 50, pp. 563-573.

Collier, P. and A. Hoeffler. 2004. "Greed and Grievance in Civil War." Oxford Economic Papers, Vol. 56, pp. 563-595.

Collier, P., A. Hoeffler, and M. Soderbom. 2004. "On the Duration of Civil War." Journal of Peace Research, Vol. 41, pp. 253-273.

Fearon, J. D. and D. D. Laitin. 2003. "Ethnicity, Insurgency and Civil War." American Political Science Review, Vol. 97, pp. 75-90.

Fraga, Arminio. 2004. "Latin America Since the 1990s: Rising from the Sickbed." Journal of Economic Perspectives, Vol. 18, pp. 89-106.

Garfinkel, M., S. Skaperdas, and C. Syropoulos. "Globalization and Domestic Conflict." Working Paper no. 0507005, Internet Documents in Economics Access Service (IDEAS), July 2005; Research Papers in Economics (RePEc) Downloadable from http://www.socsci.uci.edu/ sskaperd/gss3-apr06.pdf or from http://ideas.repec.org/p/wpa/wuwpit/0507005.html.

Gleditsch, N. P., P. Wallensteen, M. Eriksson, M. Sollenberg, and H. Strand, 2002. “Armed Conflict 1946-2001: A New Dataset," Journal of Peace Research, Vol. 39, pp. 615-637.

Hegre, H. 2002. "Some Social Requisites of a Democratic Civil Peace: Democracy, Development, and Armed Conflict." Paper presented to the American Political Science Association 2002 Annual Meeting. Boston, MA.

La Porta, F. Lopez-de-Silanes, A. Shleifer. and R. Vishny. 1998. "The Quality of Government.” National Bureau of Economic Research. Working Paper No. 6727. Cambridge, MA: NBER.

Lipton, M., R. Eastwood, and J. Kirsten. 2002. "Land and Asset Size, Structure and Distribution and the Links to Income in Three Drylands." Poverty Research Unit. Working Paper. University of Sussex, U.K. (February).

Ross, M. 2004. "What Do We Know About Natural Resources and Civil War?" Journal of Peace Research, Vol. 41, pp. 337-356.

Ocampo, J.A. 2004. "Latin America's Growth and Equity Frustrations During Structural Reforms.” Journal of Economic Perspectives, Vol. 18, pp. 67-88.

Sambanis, N. 2004. "Using Case Studies to Expand Economic Models of Civil War." Perspectives on Politics, Vol. 2, pp. 259-279. 